\title{
Методика оцінювання функціональної ефективності георадарів як засобів пошуку підповерхневої контрабанди через державний кордон
}

\author{
Микола Лисий ${ }^{\text {А }}$; Вадим Сівак ${ }^{\mathrm{B}}$; Андрій Добровольський ${ }^{\mathrm{C}}$; \\ Андрій Чуканов ${ }^{\mathrm{D}}$
}

Received: May 28, 2020 | Revised: June 10, 2020 | Accepted: June 30, 2020

DOI: $10.33445 /$ sds.2020.10.3.3

\begin{abstract}
Анотація
Результати аналізу застосування георадарів у Державній прикордонній службі України показали, що протиправна діяльності на державному кордоні, а саме застосування трубопроводів для перекачування паливо-мастильних матеріалів, спирту та тунелів для переміщення засобів контрабанди досить проблематично виявляються під поверхнею ґрунту. Недостатньо висока результативність застосування георадарів для пошуку засобів підповерхневої контрабанди через державний кордон пояснюється у першу чергу неспроможністю використовуваних зразків георадарів виявляти саме такого типу правопорушення. Існує потреба у виборі більш ефективних зразків георадарів для пошуку засобів підповерхневої контрабанди через державний кордон. 3 цією метою, із застосуванням методу експертних оцінок, розроблено методику оцінювання функціональної ефективності георадарів пошуку засобів підповерхневої контрабанди через державний кордон. Найбільшу увагу приділено визначенню чисельності групи експертів. Проблема формування складу робочої групи експертів $\epsilon$ однією із найскладніших і водночас найвідповідальніших завдань методу експертної оцінки. Існує декілька підходів до формування оптимальної чисельності групи експертів - формальних і неформальних. У роботі застосовано метод довірчих інтервалів теорії ймовірностей для встановлення взаємозв'язку між чисельністю групи експертів, кількістю характеристик георадару і довірчою ймовірністю до результатів ранжування характеристик. При цьому встановлено, що: при збільшенні кількості характеристик георадару, які ранжуються, посилюються вимоги до ймовірності хибного надання рангів характеристикам георадару, іï абсолютне значення зменшується; збільшення кількості характеристик георадару призводить до необхідності збільшення чисельності групи експертів з метою забезпечення допустимої зміни верхньої межі ймовірності хибного надання рангів характеристикам георадару; чисельність групи експертів практично не залежить від збільшення кількості характеристик георадару починаючи з оцінки 10 характеристик для визначеного значення довірчої ймовірності. Раціональним $€$ визначення мінімального складу групи експертів на рівні 3-5 осіб, що забезпечує рівень довіри до результатів ранжування 0,95-0,99 не залежно від кількості характеристик, які ранжуються.

Новим у формуванні складу експертної групи є потреба у здійсненні таких положень: визначається кількість характеристик георадару, які будуть ранжуватися; встановлюються вимоги до довірчої ймовірності результатів ранжування характеристик; кількість
\end{abstract}

\footnotetext{
А Національна академія Державної прикордонної служби України імені Богдана Хмельницького, м. Хмельницький, Україна, д.т.н., доцент, професор кафедри інженерного забезпечення та технічних засобів охорони кордону, e-mail: lisiy3152@ukr.net, ORCID: 0000-0002-9858-706X

в Національна академія Державної прикордонної служби України імені Богдана Хмельницького, м. Хмельницький, Україна, д.т.н., доцент, начальник кафедри інженерного забезпечення та технічних засобів охорони кордону, e-mail: vadimsivak@gmail.com, ORCID: 0000-0002-8262-4831

с Національна академія Державної прикордонної служби України імені Богдана Хмельницького, м. Хмельницький, Україна, к.т.н., доцент кафедри інженерного забезпечення та технічних засобів охорони кордону, e-mail: dob.andrey@gmail.com, ORCID: 0000-0001-9348-9615

D Національна академія Державної прикордонної служби України імені Богдана Хмельницького, м. Хмельницький, Україна, викладач кафедри загальновійськових дисциплін, e-mail: chukanov1990@ukr.net, ORCID: 0000-0002-7925-1026
} 
експертів, які $€$ компетентними з питань оцінювання ефективності георадарів, визначається із застосуванням ймовірнісного підходу. Загалом, структура методики оцінювання функціональної ефективності георадарів включає: формування складу робочої групи експертів, складання змісту опитувальних анкет, вибір групи значимих характеристик георадарів з усієї множини, обробка результатів опитування із використанням відомого математичного апарату оцінювання, автоматизація розрахунків.

Ключові слова: держаний кордон, підповерхнева контрабанда, підземні комунікації, георадар, метод ранжування, експерт.

\section{Постановка проблеми}

Георадар - це по суті радіолокаційна станція, використання якої дає змогу проводити перевірку ґрунту неруйнівним методом для виявлення різних об'єктів. Основним принципом роботи георадару $\epsilon$ отримання відбитого сигналу (електромагнітної хвилі) від меж поділу шарів об'єктів із різною діелектричною провідністю. Для прикладу, такими межами можуть бути природні геологічні об'єкти або щодо сфери охорони кордону, то це засоби підповерхневої контрабанди (трубопроводи, тунелі, кабелі електропередачі).

Результати аналізу, які наведено у статті [1] показали, що протиправна діяльності на державному кордоні, а саме застосування трубопроводів для перекачування паливомастильних матеріалів, спирту та тунелів для переміщення людей, як засобів контрабанди досить проблематично виявляються, не зважаючи на те, що з 2014 року на оснащенні Державної прикордонної служби України (ДПСУ) $є$ георадари типу EASYRAD.

Очевидно, що на сьогодні необхідно переосмислити загальні вимоги до георадарів, 3 врахуванням досвіду виявлення засобів підповерхневої контрабанди на державному кордоні:

- забезпечення оперативного виявлення прихованих об'єктів (трубопроводів, тунелів, у перспективі кабелів електропередачі без руйнування верхнього шару ґрунту), які знаходяться під поверхнею землі;

- забезпечення роботи протягом 5-8 годин;

- можливість виявляти металеві та неметалеві (пластик, гума) трубопроводи із невеликим діаметром;
- можливість виявляти порожнини (тунелі);

- доцільним типом слід вважати переносний георадар, оскільки досить широкий спектр фізико-географічних умов застосування на місцевості 3 обмеженою прохідністю.

Врахування таких вимог, вибір типу георадару для охорони кордону, розробка рекомендацій для Адміністрації ДПСУ щодо їх закупівлі та застосування потребує проведення оцінювання функціональної ефективності георадарів.

Питанню дослідження георадарів присвячено чимало робіт, але вони стосуються досліджень в галузях гідрогеології, екології, геології, військової сфери, будівництва [2-7].

Переглянувши досить великий обсяг публікацій можна стверджувати, що на даний час немає методики оцінювання функціональної ефективності георадарів, ефективного вибору найкращого георадара для виконання конкретних завдань. Це пояснюється відносно невеликим періодом застосування георадарів та постійним розширенням їх призначення, швидким вдосконаленням конструктивних особливостей, а також різноманітною специфікою застосування, а отже і важливістю окремих характеристик для тієї чи іншої задачі.

Так, наприклад, для військової сфери важливим $€$ забезпечення високої ймовірності виявлення з метою запобігання ураження боєприпасам, а глибина зондування практично не важлива, оскільки інженерні боєприпаси встановлюють на невеликі глибини. Для геодезії важливим навпаки $\epsilon$ глибина залягання шарів ґрунту, а час і роздільна здатність не настільки критичні характе- 
ристики. Для сфери транспорту важливим $\epsilon$ роздільна здатність утворених об'єктів під залізничним чи асфальтобетонним покриттям. Щодо охорони кордону, то важливими $\epsilon$ i глибина, і частота зондуючого сигналу, і тип георадару, його маса і час неперервної роботи.

Тому, вбачається, що розробка методики оцінювання функціональної ефективності георадарів, як і більшості інших технічних засобів має здійснюватися за єдиним комплексним показником ефективності. Зведення часткових показників до єдиного доцільно здійснювати методом експертного оцінювання, важливим етапом якого $\epsilon$ формування групи експертів, проведення ранжування тактико-технічних характеристик (далі - TTX), що і буде розглянуто далі.

\section{Аналіз останніх досліджень та публікацій}

Питання, пов'язанні 3 оцінюванням функціональної ефективності георадарів лише у деяких аспектах розглядаються в роботах [5; 8; 9] та інших авторів. У відомих публікаціях не достатньо широко висвітлюється питання отримання єдиного комплексного показника оцінки ефективності георадарів. Найбільш повно цьому питанню приділено увагу в роботі [10]. Проте, в ній дещо спрощено визначається комплексний показник, без врахування важливості окремих ТTX.

Для розв'язання такої задачі методом експертних оцінок необхідно обґрунтувати чисельність експертної групи. Проте, у наявних дослідженнях дану задачу здебільшого ототожнюють з компетентністю експертів, застосовуючи окремі аналітичні показники. Як на нашу думку, експерт вже $є$ компетентним фахівцем у вибраній галузі й очевидно більш коректнішим буде пов'язування формування групи експертів 3 ймовірнісними характеристиками правильності ранжування ТTX для послідуючого зведення їх до єдиного комплексного показника.

Найбільш повно даному питанню приділено увагу у роботі [2] проте запропонований підхід не враховує зв'язок між кількістю факторів або характеристик об'єкта, чисельністю групи експертів і ступенем довіри до ії роботи, яку можна оцінити величиною довірчої ймовірності.

Окреслені особливості оцінювання ефективності застосування георадарів обумовили формулювання сутності мети роботи.

\section{Постановка завдання}

Метою статті $€$ розробка методики оцінювання функціональної ефективності георадарів для пошуку засобів

\section{Виклад основного матеріалу}

Загалом структура методики оцінювання функціональної ефективності георадарів являє собою поетапний процес (Мал. 1).

Формування складу робочої групи експертів.

Проблема формування складу робочої групи експертів є однією із найскладніших і водночас найвідповідальніших завдань методу експертної оцінки. Існує декілька підповерхневої контрабанди через державний кордон.

підходів до формування оптимальної чисельності групи експертів - формальних і неформальних [11]. Для виконання завдання, щодо висвітлення методики оцінювання функціональної ефективності георадарів, доцільно застосувати метод ранжування із залученням експертів [10]. Розглянемо детальніше перший етап методики. 


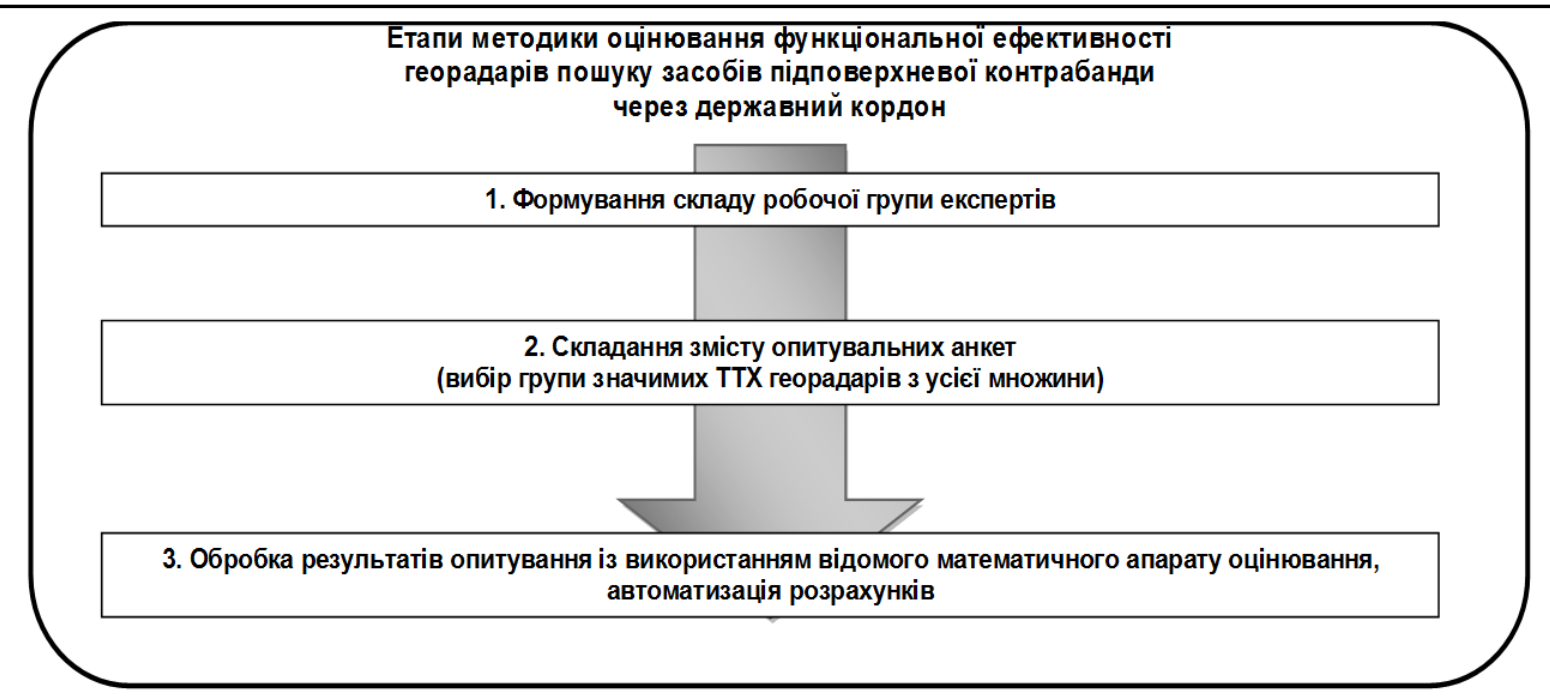

Мал. 1 - Структура методики оцінювання функціональної ефективності георадарів

Так, для встановлення меж чисельності групи розраховується максимальна і мінімальна величини. Максимальна чисельність експертної групи встановлюється на основі нерівності [10]:

$$
n{\frac{\sum_{i=1}^{n} K_{i}}{2 K_{\max }} \max ^{\prime}}^{\prime}
$$

де $n_{\max }$ - максимальне число експертів в групі; $K_{i}$ - компетентність $i$-го експерта за шкалою компетентності; $K_{\max }$ - максимально можлива компетентність експерта за шкалою компетентності.

Мінімальна чисельність експертної групи визначається за формулою:

$$
\frac{B-B^{\prime}}{B_{\max }}
$$

де $B$ - середня оцінка прогнозованої величини, в балах; $B^{\prime}$ - середня оцінка, яка дана експертною групою, з якої виключений (або $€$ навпаки, в яку включений) один експерт; $B_{\max }$ - максимально можлива оцінка прогнозованої величини в прийнятій шкалі оцінок; $\varepsilon$ - задана величина зміни середньої помилки при включенні або виключенні експерта.

Рекомендується також мінімальне значення експертної групи визначати в залежності від заданої величини зміни середньої оцінки [10]:

$$
n\left(\frac{3}{\varepsilon}+5\right)_{\min } .
$$

Відтак, чисельність групи встановлюється в межах $n_{\min } \leq n \leq n_{\max }$. Число експертів в групі можна визначити також на основі теорії вибіркового спостереження.

Середня гранична помилка частки розраховується за формулою [10]:

$$
\Delta \tilde{p}=\frac{t \cdot \sqrt{P(1-P)}}{n},
$$

де $\Delta \tilde{p}$ - середня гранична помилка частки; $t$ - критерій Стьюдента при заданому рівні істотності; $P$ - питома вага експертів, які мають певні ознаки, що встановлені організаторами експертизи (наприклад, стаж роботи в даній сфері не менше 10 років або кількість публікацій по досліджуваній проблематиці не менше п'яти та ін.); $n$ кількість експертів групи.

На підставі залежності (4) розраховується потрібна чисельність експертної групи $(n)$ за умови, що значення решти показників задані:

$$
n=\frac{t \cdot \sqrt{P(1-P)}}{\Delta \tilde{p}} .
$$

Остаточне рішення про кількісний склад експертної групи приймають організатори експертизи, враховуючи ситуацію у кожному конкретному випадку.

Нарівні 3 розрахунковими методами обчислення розміру експертної групи, рекомендується довільна чисельність 
опитуваних експертів - в межах від 10 до 20 осіб, хоча в деяких випадках допускається їх збільшення або зменшення [11], обґрунтовуючи своє рішення тим, що менша кількість експертів дає недостовірні результати, а більша ускладнює роботу групи [2]. В іншій роботі [3] запропоновано групу експертів чисельністю у 5 осіб. Остаточне рішення про кількісний склад експертної групи приймають організатори експертизи, враховуючи ситуацію у кожному конкретному випадку. Загалом, кількість експертів обирається такою, щоб статистичні методи перевірки узгодженості думок та їх усереднення давали можливість приймати обгрунтовані рішення [4].
Найбільш коректним, як на нашу думку, $є$ підхід розглянутий у [2], що базується на застосуванні ймовірнісного підходу, де встановлено зв'язок між рівнем похибки і чисельністю групи експертів. Рекомендовану кількість експертів у складі робочої групи визначається формулами [2]:

$$
\begin{gathered}
m=\frac{\sigma^{2}}{\mu^{2}}, m \geq 30, \\
m=\frac{\sigma^{2}}{\mu^{2}}+1, m<30,
\end{gathered}
$$

де $m$ - кількість експертів; $\sigma$ - дисперсія похибки; $\mu-\quad$ математичне очікування похибки.

Для окремих співвідношень дисперсій кількісний склад робочої групи експертів зведемо в таблицю 1.

Таблиця 1. - Кількісний склад робочої групи експертів

\begin{tabular}{|c|c|c|c|c|c|c|c|}
\hline$\frac{\mu^{2}}{\sigma^{2}}$ & 0,05 & 0,06 & 0,07 & 0,08 & 0,09 & 0,1 & 0,2 \\
\hline$m$ & 21 & 18 & 16 & 14 & 12 & 11 & 6 \\
\hline
\end{tabular}

Проте, у зазначених роботах не розглядається зв'язок між кількістю факторів або характеристик об'єкта, чисельністю групи експертів і ступенем довіри до їі роботи, яку можна оцінити величиною довірчої ймовірності. Оперування поняттям компетентності експертів, як на нашу думку, не $\epsilon$ достатньо коректним, оскільки експерт це особа, яка компетентна у визначеній галузі. Визначати компетентність компетентного очевидно $€$ не зовсім коректне.

3 позиції системного підходу, сукупність TTX, чисельність групи експертів, достовірність отриманих результатів оцінки $\epsilon$ єдине ціле і може бути описано методами теорії ймовірності.

Визначення важливості TTX георадарів на основі методу експертних оцінок розглянемо як випадковий процес. При цьому, під випадковою дискретною подією будемо розуміти надання кожній характеристиці георадару відповідного рангу.

Нехай ймовірність хибного надання кожній характеристиці георадару відповідного рангу становить $p$. На практиці оцінити таку ймовірність можна за частотою події $p^{*}$ в $n$ незалежних спробах оцінки. Користуючись методом довірчих інтервалів визначимо яку кількість спроб $n$ необхідно здійснити для того, щоб 3 довірчою ймовірністю $\beta$ очікувати, що похибка від заміни ймовірності їі частотою не перевищить задане значення.

Поставимо задачу у загальному виді. Нехай необхідно визначити кількість спроб $n$ надання характеристикам георадара відповідних рангів деякою чисельністю експертів $e$. Допустимо, що при цьому подія, яка полягає у хибному наданні рангів 3 ймовірністю $p$ не спостерігалась. Нехай задана довірча ймовірність $\beta$. Також, зробимо допущення, що кількість спроб надання рангів визначається як добуток:

$$
n=x \cdot e,
$$

де $e$ - чисельність групи експертів, $n$ кількість спроб надання рангів TTX георадару; $x$ - кількість ТTХ георадару. 
Тоді, для розв'язання задачі скористаємось виразом [12]:

$$
n=\frac{\lg (1-\beta)}{\lg \left(1-p_{2}\right)},
$$

де $p_{2}$ - верхня межа ймовірності хибного надання рангів характеристикам георадару; $\beta$ - довірча ймовірність до результатів ранжування характеристик георадару.

Нижня межа ймовірності хибного надання рангів характеристикам георадару звісно становить $p_{1}=0$. Значення $p_{2}$ обґрунтуємо наступним чином. Очевидно, що чим більша кількість характеристик, які оцінюються експертною групою, тим жорсткіші вимоги до ймовірності хибного надання рангу кожній характеристиці. Мінімальна кількість експертів буде необхідна за умови, що прийнятним $€$ результат коли кожен експерт всім TTХ надав вірний ранг, тобто не допустив жодного хибного рішення. Якщо експерт допустив похибку, тоді 2 характеристикам буде присвоєно невірний ранг. Похибка у надані хибного рангу для 1 характеристики немає фізичного змісту, тоді таке значення може бути прийнято за допустиме.

Нехай, наприклад, $€ 5$ TTX, ранжування яких буде запропоновано експертам. Тоді, наприклад, прийнятним результатом значення верхньої межі хибного надання рангів для 5 характеристик може бути $p_{2}=\frac{1}{5}=0,2$, для 10 характеристик відповідно $p_{2}=\frac{1}{10}=0,1, \quad$ для 15 характеристик $p_{2}=\frac{1}{15}=0,066$.

Отже виходячи із зазначеного, оцінимо кількість спроб надання рангів характеристикам георадарів при довірчій ймовірності $\beta=0,9$ і відповідно (9) при 5 і 15 TтХ маємо: $\quad n_{5}=\frac{\lg (1-0,9)}{\lg (1-0,2)} \approx 10$, $n_{15}=\frac{\lg (1-0,9)}{\lg (1-0,066)} \approx 33$.

Тоді, відповідно (8) чисельність групи експертів для 5 і 15 TTX відповідно становитиме: $\quad e_{5}=\frac{10}{5}=2$ (для 5 характеристик); $e_{15}=\frac{33}{15}=2,2 \quad$ (для 15 характеристик).

На мал. 2 подано результати розрахунку необхідної чисельності групи експертів при довірчій ймовірності до результатів оцінки $\beta=0,9$.

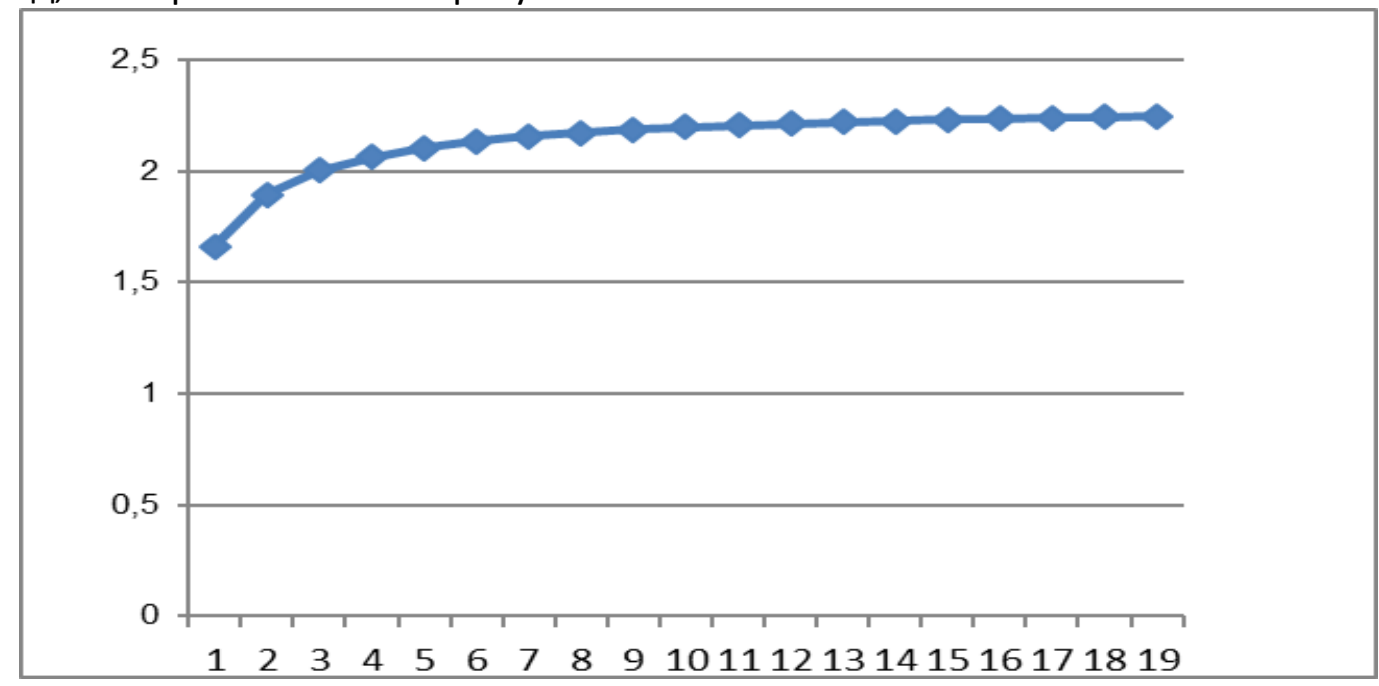

Мал. 2. Чисельність групи експертів при довірчій ймовірності до результатів оцінки $\beta=0,9$ і верхній межі ймовірності хибного надання рангів характеристикам георадару, що визначається як $p_{2}=\frac{1}{x}$ ( $x$ - кількість TTХ георадару, які оцінюються. По горизонталі відкладено $x$, по вертикалі $e$ ) 
На мал. 3 подано допустиму зміну верхньої межі ймовірності хибного надання рангів характеристикам георадару в залежності від кількості його ТTХ, які оцінюються.

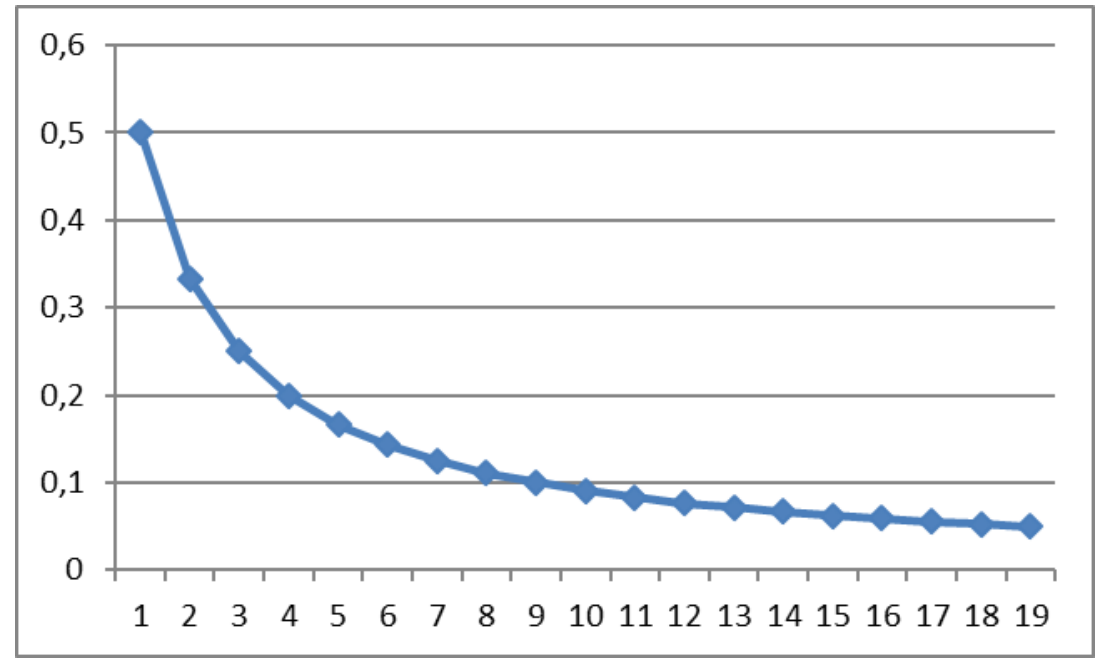

Мал. 3. Ймовірність хибного надання рангів характеристикам георадару в залежності від кількість TTX георадару, які оцінюються

На мал. 4 подано значення ймовірності хибного надання рангів характеристикам георадару в залежності від кількість ТTX георадару, які оцінюються при різних значеннях довірчої ймовірності.

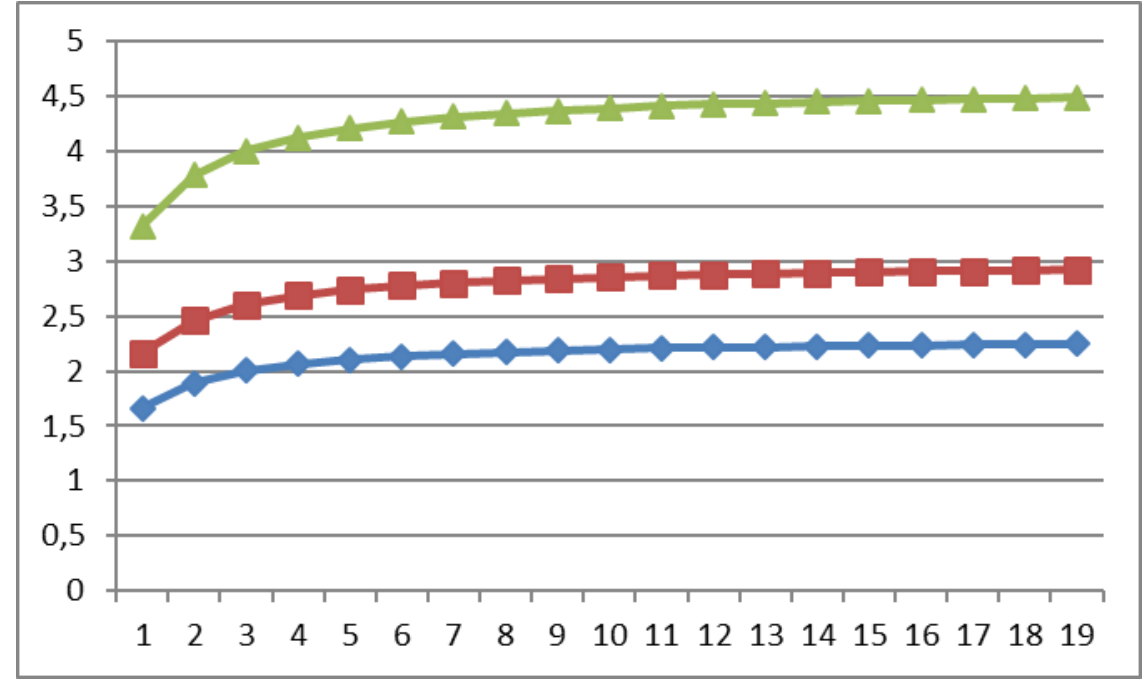

Рис. 4. Чисельність групи експертів в залежності від кількості ТTХ, які оцінюються при різних значеннях довірчої ймовірності (нижній графік $-\beta=0,9$, середній $-\beta=0,95$, верхній $-\beta=0,99$ )

Результати аналізу графіків мал. 2, 3, 4 такі:

- при збільшенні кількості TTX георадару, які ранжуються, посилюються вимоги до ймовірності хибного надання рангів характеристикам георадару, іï абсолютне значення зменшується;

- збільшення кількості ТTX георадару призводить до необхідності збільшення чисельності групи експертів 3 метою забезпечення допустимої зміни верхньої межі ймовірності хибного надання рангів характеристикам георадару;

- чисельність групи експертів практично не залежить від збільшення кількості ТTX георадару починаючи 3 оцінки 10 характеристик для визначеного значення довірчої ймовірності;

- збільшення довіри до результатів 
оцінки експертами $\beta$ на 9 \% (з 0,90 до 0,99) потребує збільшення чисельності групи експертів майже удвічі (з 2-3 до 4-5 осіб). Раціональним $€$ визначення мінімального складу групи експертів на рівні 3-5 осіб, що забезпечує рівень довіри до результатів ранжування 0,95-0,99 не залежно від кількості TTХ, які ранжуються.

Прийняті допущення і обмеження.

Допускаємо, що всі експерти $\epsilon$ компетентними, всі ранги всіма експертами надано вірно, жодної помилки не допущено, жодної розбіжності у результатах немає, але при цьому кожен експерт може помилитись в оцінці рангу не більше 1 характеристики, що по суті не має фізичного змісту, оскільки мінімально можливим $€$ допущення 2 помилок у визначенні рангів. Допущення зроблене виходячи з того, що кожна особа, яка призначена експертом $€$ компетентною в даній галузі. Зв'язок окремої характеристики 3 кінцевим результатом ефективності застосування георадару $\epsilon$ досить неоднозначним, тому, експерт компетентно обґрунтовує своє рішення, яке може і не співпадати 3 іншими. Саме за такого допущення вплив окремих характеристик буде зменшуватись на результуючу згортку характеристик, при цьому зберігатиметься вірна загальна тенденція оцінки ефективності засобу.

Обмежуємо довірчу ймовірність до результатів ранжування характеристик георадару на рівні 0,95-0,99.

Новим у формуванні складу експертної групи є потреба у здійсненні таких положень:

1. Визначається кількість характеристик георадару, які будуть ранжуватися.

2. Встановлюються вимоги до довірчої ймовірності результатів ранжування ТTХ.

3. Кількість експертів, які $\epsilon$ компетентними 3 питань оцінювання ефективності георадарів, визначається із застосуванням ймовірнісного підходу.

Складання змісту опитувальних анкет.

В анкеті пропонується здійснити ранжування TTX георадарів. Як було показано, кількість ТTX пропорційна чисельності групи експертів. Тому, важливо обмежитись розглядом не всієї сукупності характеристик, лише значимої групи. До того ж, при згортці великої кількості ТTХ, знецінюється значимість основних, визначальних TTX георадарів. Попередньо, відповідно результатів аналізу ТTX георадарів, встановлено, що значимими $€ 5$ TTX, а саме: глибина виявлення об'єкта, роздільна здатність за глибиною виявлення, тривалість роботи, маса, довжина хвилі передавача. Загалом виробники георадарів надають до 15 TTX.

Обробка результатів опитування із використанням відомого математичного апарату оцінювання, автоматизація розрахунків.

На даному етапі методики використано метод ранжування, тобто експерт, опираючись на свій досвід, має розмістити характеристики георадарів у певному порядку, надати певній характеристиці свій ранг, відповідно найбільш значущий буде мати ранг 1 , і ранг $N$ - найменший. Кількість рангів відповідає кількості ранжувальних характеристик.

Опираючись на роботу [10] та проведений аналіз застосування георадарів встановлюють перелік значимих характеристик, які відображають їх властивості та узагальнюють чисельні значення $\left\{A_{i j}\right\}$-характеристики для кожного зразка георадару.

В подальшому опитують групу із $G$ експертів. Кожен $g$-й експерт визначає набір чисел $C_{j g}, j=\overline{1, j}$ які відображають його погляд про пріоритетність технічних характеристик георадарів. Кожен експерт має розташовувати технічні характеристики у порядку їх значимості (важливості) i приписати кожному із них числа натурального ряду: $1,2, \ldots$ 5. Ранг показника визначають його номером, якщо на його місці у ряду відсутні будь-які інші. Коли на одному місці маємо декілька показників, що не розрізняються (мають зв'язані ранги), то ранг кожного 3 них дорівнює середньоарифметичному їх нових номерів. При цьому кількість рангів показників дорівнює $R$. 
Під час визначення коефіцієнтів $C_{j g}$ приймається, що між рангом і важливістю характеристики георадару існує лінійна залежність. Тоді визначення коефіцієнтів $C_{j g}$ здійснюють за формулою [10]:

$$
C_{j g}=1-\frac{r_{j g}-1}{R},
$$

де $r_{i g}$ - ранг відповідного $j$-ї характеристики георадару за думкою $g$-го експерта.

Після цього значення $C_{j g}$ нормуються [10]:

$$
\beta_{j g}=\frac{C_{j g}}{\sum_{j=1}^{j} C_{j g}} ; \sum_{j=1}^{j} \beta_{j g}=1 .
$$

Остаточно значення коефіцієнтів важливості $\beta_{j}$ обчислюють усередненням значень $\beta_{\text {jg }}$ які надходять від усіх експертів. Коли компетентність експертів у групі вважається однаковою [10]:

$$
\beta_{j}=\frac{1}{G} \sum_{g-1}^{G} \beta_{j g} ; g=\overline{1, G} .
$$

Вірогідність результатів експертного оцінювання характеризується ступенем узгодженості оцінок, які надають експерти. Для цього використовують коефіцієнт конкордації $(W)$, який визначають за формулами [10]:

$$
\begin{aligned}
& \mathrm{W}=\frac{12 \mathrm{~B}}{\mathrm{G}^{2}\left(R^{3}-R\right)-G \sum_{g-1}^{G} T_{g}} ; g=\overline{1, G}, \\
& \mathrm{~B}=\sum_{I-1}^{R}\left(\sum_{g-1}^{G} r_{\mathrm{lg}}-\frac{1}{R} \sum_{l-1}^{R} \sum_{g-1}^{G} r_{\mathrm{lg}}\right)^{2} ; I=\overline{1, R}, \\
& T_{g}=\sum_{\phi-1}^{H_{g}}\left(h_{\phi g}^{3}-h_{\phi g}\right) ; g=\overline{1, G},
\end{aligned}
$$

де $\mathrm{T}_{\mathrm{g}}$ - показник зв'язаних рангів у g-му ранжируванні. Коли ранги, які збігаються (зв'язні), відсутні, $\mathrm{T}_{\mathrm{g}}=0 ; \mathrm{H}_{\mathrm{g}}$ - кількість груп рівних рангів у g-му ранжируванні; $\mathrm{h}_{\phi g}-$ кількість рівних рангів у $\varphi$-й групі ранжирування зв'язаних рангів під час ранжирування $g$-м експертом.
Значення коефіцієнта конкордації перебуває у межах $0<\mathrm{W}<1$. При цьому $\mathrm{W}=0$ означає повну протилежність, а $\mathrm{W}=1$ - повне збігання ранжирувань. Вірогідність вважається доброю, коли $\mathrm{W}=0,7-0,8$.

Проте, методика може бути спрощеною, якщо характеристики за важливістю вважаються рівними між собою, то показник пріоритетності кожної із них визначають співвідношенням типу $1 / J$, де $J$ - загальна кількість характеристик оцінюваних зразків георадарів. Проте, такий підхід потребує попереднього експертного оцінювання, відбору таких характеристик, що не спрощує рішення задачі.

Для оцінювання використовують чисельні значення найбільш важливих технічних характеристик, встановлюють правило критерію, за яким з усієї вибірки покроково обирають найкращий (умовно-еталонний) зразок георадару [10]:

$$
A_{e j}=\max A_{i j}, i=\overline{1 \ldots N},
$$

або

$$
A_{e j}=\min A_{i j}, i=\overline{1 \ldots N},
$$

де $A_{i j}$ - абсолютне значення j-ї властивості $i$ го зразка георадару, що порівнюється; $A_{e j}$ абсолютне значення цієї властивості у еталонного зразку (базового зразка).

Визначають відносні персональні показники кожного зразка георадару для кожної характеристики, які для властивостей "більше-краще":

$$
q_{i j}=\frac{A_{i j}}{A_{e j}},
$$

а для властивостей “більше-гірше”

$$
q_{i j}=\frac{A_{e j}}{A_{i j}},
$$

Для властивостей, які виражаються у вигляді “ $\epsilon$ " чи “немає”

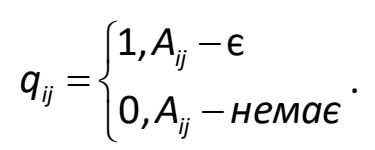

Для будь-яких властивостей $q_{e j}=1$, якщо $A_{1 j}=A_{2 j}=\ldots A_{n j}=A_{e j} \neq 0$.

Такими 
властивостями можуть бути методи обробки сигналів у георадарах, принципи функціонування, ремонтопридатність та інше.

у подальшому розраховують середньозважений комплексний показник якості кожного зразка георадару. Комплексний показник $i$-го зразка $Q_{i}$ визначають за адитивною згорткою [10]:

$$
Q_{i}=\sum_{j=1}^{J} \beta_{j} q_{i j}
$$

де $\beta_{j}-$ коефіцієнт вагомості $j$-ї технічної характеристики; $q_{i j}=1$ - відносний одиничний показник $j$-ї технічної характеристики $і$-го зразка.

Нормують одержані значення комплексного показника якості кожного зразка георадару по відношенню до найбільшого значення [10]:

$$
K_{i}=\frac{Q_{j}}{\max Q_{j}} .
$$

Встановлюють ранги кожного зразка георадару за рівнем якості та роблять висновок про пріоритетність оцінюваних зразків георадарів, що дозолить визначити переваги та вимоги до характеристик, які потребують поліпшення для існуючих на озброєнні георадарів.

\section{Висновки}

Отже, уперше розроблено методику оцінювання функціональної ефективності георадарів пошуку об'єктів підповерхневої контрабанди через державний кордон. Сутність новизни методики полягає у застосуванні методу довірчих інтервалів теорії ймовірностей для встановлення взаємозв'язку між чисельністю групи експертів, кількістю характеристик георадару і довірчою ймовірністю до результатів ранжування характеристик. Це дозволило встановити, що раціональним $є$ мінімальний склад групи експертів на рівні 3-5 осіб, що забезпечує рівень довіри до результатів ранжування 0,95-0,99 не залежно від кількості TTX, які ранжуються.

Подальшими дослідженнями $\epsilon$ оцінювання функціональної ефективності георадарів із застосуванням програмного забезпечення, а також розробка пропозицій щодо закупівлі зразків для потреб служби.

\section{Список використаних джерел}

1. Шинкарук, О., Лисий, М., Бабій, Ю., Чуканов А. (2019). Аналіз стану протиправної діяльності на державному кордоні України із застосуванням засобів підповерхневої контрабанди. Збірник наукових праць Національної академії Державної прикордонної служби України. Сер. : Військові та технічні науки. № 2. С. 364-403.

2. Стрельбіцький, М. А., Равлюк, В. В., Ваврічен, О. А. (2018). Методика експертного оцінювання ступеня впливу на інформаційні системи дестабілізуючих факторів, викликаних стадією модернізації. Збірник наукових праць Національної академії Державної прикордонної служби України. Сер. : Військові та технічні науки. № 2. С. 271-283.
3. Трасковецька, Л. М., Боровик, Л. В. (2013). Автоматизація математичних методів експертних оцінок. Збірник наукових праць Національної академії Державної прикордонної служби України. Сер. : Військові та технічні науки. № 2. С. 373-384.

4. Шуренок, В. А, Коріненко, В. І., Бовсуновський, В. Ю. (2010). Методика врахування узгодженості експертної інформації при визначенні режимів роботи багатофункціональної радіостанції. Сучасні інформаційні технології у сфері безпеки та оборони. № 2. С. 29-33.

5. Залевський, Г. С. (2011). Технічні вимоги до системи виявлення і ідентифікації вибухонебезпечних об'єктів у ґрунті та поблизу його поверхні. Системи озброєння і військова техніка. № 2. С. 53-57. 
6. Pochanin, G. P., Masalov, S.A., Ruban, V.P., Kholod, P.V., Batrakov, D.O., Batrakova, A.G, Varianytsia-Roshchupkina, L.A., Urdzik, S.N., Pochanin, O.G. (2016). Advances in ShortRange Distance and Permittivity GroundPenetrating Radar Measurements for Road Surface Surveying Chapter 2 / in th book Advanced Ultrawideband Radar: Signals, Targets, and Applications Ed. by J.D. Taylor. CRC Press. P.19-64.

7. Варяница-Рощупкина, Л. А. (2015). Просторово-часові трансформації імпульсної електромагнітної хвилі при дифракції на підповерхневих об'єктах: автореф. дис. ... канд. фріз.-мат. наук : 01.04 .03 / НАН України, Інститут радіофрізики та електроніки ім. О.Я. Усикова. Харків. 20 с.

8. Янковский, К. П. (2002). Оценка диагностических возможностей систем георадарного зондирования природных и природно-антропогенных объектов : дис. ... канд. тех. наук: 25.00.36 / Институт космических исследований РАН. Москва. 141 c.

9. Букін, О. В. (2018) Багаточастотне когерентне радіозондування підповерх-невого середовища : авторефр. дис. ... канд. фіз.мат. Наук: 01.04.03 / НАН України, Інститут радіофрізики та електроніки ім. О. Я. Усикова. Харків. 20 с.

10. Коцюруба, В.І. та ін. (2015). Оперативні розрахунки завдань інженерного забезпечення (методика та приклади): навчально-методичний посібник / колектив авторів. К.: НУОУ ім. Івана Черняховського. 148 с.

11. Грабовецький, Б.Є. (2010). Методи експертних оцінок: теорія, методологія, напрямки використання : монографрія. Вінниця : ВНТУ. 171 с.

12. Вентцель, Е. С. (1969). Теория вероятностей : Учебник для вузов. 4-е изд. Москва : Наука. 576 c.

\title{
Методика оценивания функциональной эффективности
} георадаров как средств поиска подповерхностной контрабанды через государственную границу

\footnotetext{
Николай Лысый ${ }^{\text {; }}$ Вадим Сивак ${ }^{\mathrm{B}}$; Андрей Добровольский ${ }^{\mathrm{C}}$; Андрей Чуканов ${ }^{\mathrm{D}}$

А Национальная академия Государственной пограничной службы Украины имени Богдана Хмельницкого, г. Хмельницкий, Украина, д.т.н., доцент, профессор кафедры инженерного обеспечения и технических средств охраны границы, e-mail: lisiy3152@ukr.net

В Национальная академия Государственной пограничной службы Украины имени Богдана Хмельницкого, г. Хмельницкий, Украина, д.т.н., доцент, начальник кафедры инженерного обеспечения и технических средств охраны rраницы, e-mail: vadimsivak@gmail.com,

С Национальная академия Государственной пограничной службы Украины имени Богдана Хмельницкого, г. Хмельницкий, Украина, к.т.н., доцент кафедры инженерного обеспечения и технических средств охраны границы, e-mail: dob.andrey@gmail.com,

D Национальная академия Государственной пограничной службы Украины имени Богдана Хмельницкого, г. Хмельницкий, Украина, преподаватель кафедры общевойсковых дисциплин, e-mail: chukanov1990@ukr.net
}

\begin{abstract}
Аннотация
Результаты анализа применения георадаров в Государственной пограничной службе Украины показали, что противоправная деятельность на государственной границе, а именно применение трубопроводов для перекачивания топливо-смазочных материалов, спирта и туннелей для перемещения средств контрабанды довольно проблематично отыскиваются под поверхностью грунта. Недостаточно высокая результативность применения георадаров для поиска средств подповерхностной контрабанды через государственную границу объясняется в первую очередь невозможностью используемых образцов георадаров выявлять именно такого типа правонарушения. Существует необходимость в выборе более эффективных образцов георадаров для поиска средств подповерхностной контрабанды через государственную границу. С этой целью, с применением метода экспертных оценок, разработана
\end{abstract}


методика оценивания функциональной эффективности георадаров для поиска средств подповерхностной контрабанды через государственную границу. Самое большое внимание уделено определению численности группы экспертов. Проблема формирования состава рабочей группы экспертов есть одной из сложнейших и вместе с тем ответственной задачей метода экспертной оценки. Существует несколько подходов к формированию оптимальной численности группы экспертов - формальных и неформальных. В работе применен метод доверительных интервалов теории вероятностей для установления взаимосвязи между численностью группы экспертов, количеством характеристик георадара и доверительной вероятностью к результатам ранжирования характеристик. При этом установлено, что: при увеличении количества характеристик георадара, которые ранжируются, усиливаются требования к вероятности ошибочного предоставления рангов характеристикам георадара, ее абсолютное значение уменьшается; увеличение количества характеристик георадара приводит к необходимости увеличения численности группы экспертов с целью обеспечения допустимого изменения верхней границы вероятности ошибочного предоставления рангов характеристикам георадара; численность группы экспертов практически не зависит от увеличения количества характеристик георадара начиная с оценки 10 характеристик для определенного значения доверительной вероятности. Рациональным является определение минимального состава группы экспертов на уровне 3-5 лиц, которая обеспечивает уровень доверия к результатам ранжирования 0,95-0,99 не в зависимости от количества характеристик, которые ранжируются. Новым в формировании состава экспертной группы есть потребность в осуществлении таких положений: определяется количество характеристик георадара, которые будут ранжироваться; устанавливаются требования к доверительной вероятности результатов ранжирования характеристик; количество экспертов, которые являются компетентными по вопросам оценивания эффективности георадаров, определяется с применением вероятностного подхода. В общем, структура методики оценивания функциональной эффективности георадаров включает: формирование состава рабочей группы экспертов, составление содержания опросных анкет, выбор группы значимых характеристик георадаров из всего множества, обработка результатов опрашивания с использованием известного математического аппарата оценивания, автоматизация расчетов.

Ключевые слова: государственная граница, подповерхностная контрабанда, подземные коммуникации, георадар, метод ранжирования, эксперт.

\section{Methodology for assessing the functional effectiveness of georadars as a means of searching for subsurface smuggling across the state border}

\footnotetext{
Mykola Lysyi ${ }^{A}$; Vadym Sivak ${ }^{B}$; Andrii Dobrovolskyi ${ }^{C}$; Andrii Chukanov ${ }^{D}$

A National Academy of the State Border Service of Ukraine named after Bogdan Khmelnitsky, Khmelnitsky, Ukraine, Doctor of Technical Sciences, Associate Professor, Professor of the Department of Engineering Support and Technical Means of Border Protection, e-mail: lisiy3152@ukr.net

B National Academy of the State Border Service of Ukraine named after Bogdan Khmelnitsky, Khmelnitsky, Ukraine, Doctor of Engineering, Associate Professor, Head of the Department of Engineering Support and Technical Means of Border Protection, e-mail: vadimsivak@gmail.com

${ }^{\mathrm{C}}$ National Academy of the State Border Service of Ukraine named after Bogdan Khmelnitsky, Khmelnitsky, Ukraine, Ph.D., Associate Professor, Department of Fundamentals of Radio Engineering, e-mail: dob.andrey@gmail.com

D National Academy of the State Border Service of Ukraine named after Bogdan Khmelnitsky, Khmelnitsky, Ukraine, lecturer of the Department of Combined Arms, e-mail: chukanov1990@ukr.net
}

\section{Abstract}

The results of the analysis of the use of georadars in the State Border Service of Ukraine have shown, that illegal activities at the state border, namely the use of pipelines for pumping fuel and lubricants, alcohol and tunnels for moving smuggling are quite problematic under the 
ground. The low efficiency of the use of georadars to search for means of subsurface smuggling across the state border is primarily explained by the inability of the used samples of georadars to detect this type of offense. There is a need to select more effective samples of georadars to find means of subsurface smuggling across the state border. To this end, using the method of expert assessments, a method for evaluating the functional efficiency of land-based georadars search facilities for contraband across the state border has been developed. The greatest attention was paid to determining the size of the expert group. The problem of forming the composition of the expert working group is one of the most difficult and at the same time the most responsible tasks of the method of peer review. There are several approaches to forming the optimal number of experts - formal and informal. The method of confidence intervals of the theory of probabilities is used in the labor, to establish the relationship between the size of the expert group, the number of characteristics of the georadar and the confidence probability to the results of the ranking of characteristics. It was found that: as the number of georadars characteristics increases, the requirements for the probability of erroneously rendering ranks of the radar characteristics increase, its absolute value decreases; an increase in the number of georadars characteristics leads to the need to increase the number of experts to ensure that the upper bound on the likelihood of erroneously assigning ranks to the characteristics of the georadars are allowed; the size of the expert group is almost independent of the increase in the number of characteristics of the georadars, starting with an estimate of 10 characteristics for a certain value of confidence. It is reasonable to determine the minimum composition of a panel of experts at the level of 3-5 people, who provide a level of confidence in the ranking results of 0.95-0.99 regardless of the number of characteristics that are ranked. New in the formation of the expert group is the need to implement the following provisions: determine the number of characteristics of the georadar to be ranked; requirements for the credibility of performance ranking results are established; the number of experts, who are competent in assessing the effectiveness of georadars is determined using a probabilistic approach. In general, the structure of the method of assessing the functional efficiency of the georadars includes: forming the composition of the working group of experts, drafting the content of questionnaires, selecting a group of significant characteristics of the georadars from the entire set, processing the results of the survey using a known mathematical estimation apparatus, automation of calculations.

Keywords: the state border, subsurface smuggling, underground communications, georadar, ranking method, expert.

\section{References}

1. Shynkaruk, O., Lysyi, M., Babii, Yu., Chukanov A. (2019). Analiz stanu protypravnoi diialnosti na derzhavnomu kordoni Ukrainy iz zastosuvanniam zasobiv pidpoverkhnevoi kontrabandy. Zbirnyk naukovykh prats Natsionalnoi akademii Derzhavnoi prykordonnoi sluzhby Ukrainy. Ser. : Viiskovi ta tekhnichni nauky. № 2. S. 364-403.

2. Strelbitskyi, M.A., Ravliuk, V.V., Vavrichen, O.A. (2018). Metodyka ekspertnoho otsiniuvannia stupenia vplyvu na informatsiini systemy destabilizuiuchykh faktoriv, vyklykanykh stadiieiu modernizatsii. Zbirnyk naukovykh prats Natsionalnoi akademii Derzhavnoi prykordonnoi sluzhby
Ukrainy. Ser. : Viiskovi ta tekhnichni nauky. № 2. S. 271-283.

3. Traskovetska, L.M., Borovyk, L.V. (2013). Avtomatyzatsiia matematychnykh metodiv ekspertnykh otsinok. Zbirnyk naukovykh prats Natsionalnoi akademii Derzhavnoi prykordonnoi sluzhby Ukrainy. Ser. : Viiskovi ta tekhnichni nauky. № 2. S. 373-384.

4. Shurenok, V.A, Korinenko, V.I., Bovsunovskyi, V. Yu. (2010). Metodyka vrakhuvannia uzghodzhenosti ekspertnoi informatsii pry vyznachenni rezhymiv roboty bahatofunktsionalnoi radiostantsii. Suchasni informatsiini tekhnolohii u sferi bezpeky ta oborony. № 2. S. 29-33. 
5. Zalevskyi, H.S. (2011). Tekhnichni vymohy do systemy vyiavlennia i identyfikatsii vybukhonebezpechnykh obiektiv u grunti ta poblyzu yoho poverkhni. Systemy ozbroiennia i viiskova tekhnika. № 2. S. 53-57.

6. Pochanin, G. P., Masalov, S.A., Ruban, V.P., Kholod, P.V., Batrakov, D.O., Batrakova, A.G, Varianytsia-Roshchupkina, L.A., Urdzik, S.N., Pochanin, O.G. (2016). Advances in ShortRange Distance and Permittivity GroundPenetrating Radar Measurements for Road Surface Surveying Chapter 2 / in th book Advanced Ultrawideband Radar: Signals, Targets, and Applications Ed. by J.D. Taylor. CRC Press. P.19-64.

7. Varianytsa-Roshchupkyna, L.A. (2015). Prostorovo-chasovi transformatsii impulsnoi elektromahnitnoi khvyli pry dyfraktsii na pidpoverkhnevykh obiektakh: avtoref. dys.... kand. fiz.-mat. nauk : 01.04.03 / NAN Ukrainy, Instytut radiofizyky ta elektroniky im. O.la. Usykova. Kharkiv. $20 \mathrm{~s}$.

8. lankovskyi, K.P. (2002). Otsenka dyahnostycheskykh vozmozhnostei system heoradarnoho zondyrovanyia pryrodnukh y pryrodno-antropohennыkh obъektov : dys.... kand. tekh. nauk : 25.00.36 / Ynstytut kosmycheskykh yssledovanyi RAN. Moskva. $141 \mathrm{~s}$.

9. Bukin, O. V. (2018) Bahatochastotne koherentne radiozonduvannia pidpoverkhnevoho seredovyshcha : avtoref. dys. ... kand. fiz.-mat. Nauk : 01.04.03 / NAN Ukrainy, Instytut radiofizyky ta elektroniky im. O. Ya. Usykova. Kharkiv. $20 \mathrm{~s}$.

10. Kotsiuruba, V.I. ta in. (2015). Operatyvni rozrakhunky zavdan inzhenernoho zabezpechennia (metodyka ta pryklady): navchalno-metodychnyi posibnyk / kolektyv avtoriv. K.: NUOU im. Ivana Cherniakhovskoho. $148 \mathrm{~s}$.

11. Hrabovetskyi, B.le. (2010). Metody ekspertnykh otsinok: teoriia, metodolohiia, napriamky vykorystannia : monohrafiia. Vinnytsia : VNTU. $171 \mathrm{~s}$.

12. Venttsel, E.S. (1969). Teoryia veroiatnostei : Uchebnyk dlia vuzov. 4-e yzd. Moscow : Nauka. 576 s. 